Vásquez, J.G. (2015). La forma de las ruinas. Bogotá: Penguin Random House Grupo Editorial, S.A.S.

\title{
MEMORIA E IDENTIDAD EN LA FORMA DE LAS RUINAS DE JUAN GABRIEL VÁSQUEZ
}

\author{
Jaisully Durán* \\ Universidad del Valle \\ "No sé cuándo comencé a darme cuenta de que el pasado \\ de mi país me resultaba incomprensible y oscuro" \\ Juan Gabriel Vásquez, La forma de las ruinas
}

La forma de las ruinas, publicada en Bogotá en noviembre de 2015 por el Grupo Editorial Penguin Random House, revela la preocupación del autor por el impacto de la violencia en la configuración de la memoria colectiva e individual en Colombia; expone cómo una revisión crítica del pasado puede redefinir nuestra comprensión del presente y la construcción del futuro. La Historia de Colombia y la historia de colombianos tocados por la violencia se enlazan a lo largo de nueve capítulos y sus 549 páginas, señalan algunos de los momentos y personajes más relevantes en la vida política y social de Colombia a finales del siglo XIX y durante el XX: los asesinatos de Rafael Uribe y Jorge Eliécer Gaitán. Sin embargo, más allá de una exhaustiva indagación histórica la novela ofrece una interesante perspectiva sobre cómo asumir la Historia de nuestro país, cuestiona por qué y para qué recordar nuestro pasado.

Los caudillos liberales Uribe y Gaitán representan momentos álgidos de la violencia bipartidista, que ha sido uno de los ejes fundamentales de la novela colombiana. Pero a diferencia de las primeras obras que abordaron la Violencia, La forma de las ruinas expone un panorama

*Egresada de la Universidad del Valle, Cali. Coordinadora académica del programa de Licenciatura en Literatura de la Universidad del Valle, sede Palmira. Publicó el artículo Vida intelectual y ensayo en Reyes, Volpi y Ospina (2016), en la revista Estudios de literatura colombiana de la Universidad de Antioquia. Actualmente trabaja en un proyecto de investigación acerca de la relación entre memoria, violencia y literatura en Colombia. 
mucho más amplio a través de un imbricado relato que supera el efecto de los testimonios inmediatos y las descripciones sanguinarias entre rivales políticos; y se instala con la distancia necesaria (que le da su ubicación temporal) para reflexionar sobre los efectos de la violencia en la sociedad colombiana desde el siglo XIX hasta el XXI.

La forma de las ruinas es la historia de Carlos Carballo, un hombre que no conoció a su padre, pues éste fue asesinado cuando él era tan solo un bebé. Aun así, su memoria familiar, encarnada en la figura del abuelo materno, le servirá para afianzar sus vínculos con los relatos, las interpretaciones y las emociones de un pasado que no vivió, pero del cual recibió los vestigios de una pérdida personal y los efectos de una historia que parece repetirse en Colombia: anular la diferencia. A partir de ese momento, aunque parece que las teorías de la conspiración son las que rigen su vida, entabla un diálogo entre el pasado, el presente y el futuro: dedica su vida a entender qué vio su padre, fiel seguidor de Gaitán, momentos antes de morir el fatídico 9 de abril de 1948.

Pero este matiz de la vida familiar de Carballo solo se descubre a medida que el narrador-personaje Juan Gabriel Vásquez aclara la conexión entre el pasado y presente de su propia historia; y logra comprender cómo la memoria y el olvido atraviesan la identidad de los sujetos aun creyéndose ajenos a los conflictos de violencia en Colombia. Así, Vásquez nos revela finalmente que Carballo no es tan solo un obsesionado con la Historia, sino un ser marcado por los discursos de violencia que incidieron no solo en su familia sino en su propio destino.

El objetivo de recuperar la vértebra perdida de Jorge Eliécer Gaitán es uno de los detonantes de la novela. Esto da inicio a un falso compromiso del narrador-personaje Vásquez para redactar una historia de conspiración propuesta por Carlos Carballo, quien posee la vértebra. Finalmente, Vásquez descubre que el informe que construyó, tras intensos diálogos con este personaje, es "un mausoleo de palabras" para César, el padre de Carballo; y que gracias a él indaga acerca de su propia relación con el pasado, el presente y el futuro.

El título La forma de las ruinas más allá de referirse a las ruinas de los objetos que obsesionaban a Carballo: la vértebra de Gaitán y la parte superior del cráneo de Uribe, es una invitación a reflexionar en torno 
a qué hacer con esos rastros del pasado, qué injerencia tienen sobre el presente, cómo les damos sentido, cómo pueden modificar la vida de las personas. El título también nos lleva a cuestionar hasta dónde comprendemos el presente desconociendo un pasado que ha definido los rasgos de una sociedad, de una identidad, de una vida. ¿Hacia dónde dirigir el horizonte?, ¿es necesario olvidar o comprender nuestro pasado? Pues bien, Carballo es la representación de un ser que decide intentar comprender un pasado de violencia que definió su vida, para significar y afirmar su presente.

Por otro lado, el narrador-personaje Vásquez nutre su relato con las voces de otros personajes y documentos históricos. Por ejemplo, dedica cuatro capítulos de su "informe" al homicidio del General Rafael Uribe y al desarrollo de la investigación de Marco Tulio Anzola sobre este asesinato, así como su libro Asesinato del General Uribe Uribe: quiénes son?(1917). Este es uno de los recursos que utiliza el narrador para ubicarnos en un contexto histórico en el cual predominan los discursos eclesiásticos y políticos que incentivan la dualidad amigoenemigo y que promueven y justifican las acciones violentas entre y hacia los ciudadanos.

Finalmente, la novela representa un gran aporte a una de las discusiones que lideran el contexto actual colombiano en torno al proceso de paz: la memoria, el perdón, el olvido.

"La memoria una aliada para la paz", discurso que dirige el Centro Nacional de Memoria Histórica, es la apuesta por auscultar el pasado, la Historia y las historias, con una clara intención de construir un futuro sin acudir una vez más a la dualidad amigo-enemigo. En este sentido, Vásquez se une a las reflexiones que como colombianos de cualquier generación debemos plantearnos: ¿Cuál es la validez de los discursos de violencia para edificar el presente? ¿Por qué heredar a las siguientes generaciones una memoria de guerra, de anulación de la diferencia? ¿Qué aspectos del pasado nutrirán positivamente nuestro futuro? Es así como el periodista David Rieff expresa: "Sin olvido, seríamos monstruos heridos, sin perdón dado o recibido...y, suponiendo que hemos estado prestando atención, seríamos inconsolables". 


\section{JAISULLY DURÁN}

La forma de las ruinas es un acertado y ameno diálogo con la Historia y la ficción, un goce estético e intelectual. A lo largo de sus 549 páginas asistiremos a las transformaciones axiológicas, cognitivas y emocionales de los personajes; incluso, también podría ser a la nuestra. 